\title{
RANCANG BANGUN SISTEM INFORMASI PENILAIAN BEBAN KERJA DOSEN
}

\author{
Fajar Nugraha \\ Fakultas Teknik, Program Studi Sistem Informasi \\ Universitas Muria Kudus \\ Email: fajar.nugraha@umk.ac.id \\ Wiwit Agus Triyanto \\ Fakultas Teknik, Program Studi Sistem Informasi \\ Universitas Muria Kudus \\ Email: wiwit.agus@umk.ac.id \\ Muhammad Arifin \\ Fakultas Teknik, Program Studi Sistem Informasi \\ Universitas Muria Kudus \\ Email: muhammad.arifin.umk.ac.id \\ Yuniarsi Rahayu \\ Fakultas Ilmu Komputer, Program Studi Teknik Informatika \\ Universitas Dian Nuswantoro \\ Email: yuniarsi.rahayu@dsn.dinus.ac.id
}

\begin{abstract}
ABSTRAK
Penelitian ini mengembangkan sebuah rancang bangun sistem informasi penilaian beban kerja dosen untuk melakukan pengelolaan pada kegiatan tridharma perguruan tinggi. Penilaian beban kerja dosen merupakan salah satu indikator kinerja seorang dosen dalam pelaksanaan tridharma perguruan tinggi. Dalam pelaksanaannya tugas bagi dosen ini diperlukan evaluasi serta pelaporan sebagai bentuk pertanggungjawaban kepada pihak yang berkepentingan atau pemangku kebijakan. Pelaksanan evaluasi dan pelaporan tersebut dapat dikembangkan menjadi sebuah sistem informasi beban kerja dosen untuk membantu dosen dalam pengelolaan serta pelaporan kegiatam tridarma yang telah dilaksanakannya. Kegiatan yang dikelola dalam sistem ini antara lain kegiatan pendidikan dan pengajaran, penelitian, pengabdian serta unsur penunjang. Rancang bangun sistem penilaian beban kerja dosen ini mengadopsi metode pengembangan sistem waterfall serta metode perancangan menggunakan $U M L$. Rancang bangun sistem informasi penilaian beban kerja dosen ini bertujuan untuk pengelolaan kegiatan tridharma serta proses evaluasi dan penilaiannya sehingga dapat membantu dalam pelaporan kegiatan tridharma sebuah perguruan tinggi dan seluruh kegiatan tridharma seorang dosen. Hasil dari rancang bangun ini adalah sebuah sistem informasi yang digunakan dalam melakukan pengelolaan serta evaluasi dan penilaian beban kerja dosen.
\end{abstract}

Kata kunci: sistem informasi; beban kerja dosen; tridharma.

\begin{abstract}
This research develops an information system design for evaluating the workload of lecturers to manage the activities of the higher education tridharma. Assessment of lecturer workload is one of the indicators of the performance of a lecturer in the implementation of the university's tridharma In carrying out this task for lecturers, evaluation and reporting are needed as a form of accountability to interested parties or stakeholders. Implementation of evaluation and reporting can be developed into an information system for lecturer workload to assist lecturers in management and reporting on tridarma activities that have been implemented. Activities managed in this system include educational and teaching activities, research, service and supporting elements. The design of the lecturer workload assessment system adopts the waterfall system development method and the design method using UML. The design of information systems for assessing the workload of lecturers is aimed at managing tridharma activities as well as the evaluation and assessment process so that they can assist in reporting the activities of tridharma of a college and all tridharma activities of a lecturer. The results of the design are an information system used in managing and evaluating the workload of lecturers.
\end{abstract}

Keywords: information systems; lecturer workload; tridharma. 


\section{PENDAHULUAN}

Dosen merupakan sorang pendidik profesional yang berdasarkan pendidikan, keilmuan serta keahliannya diangkat dan diberikan tugas oleh penyelenggara perguruan tinggi untuk melaksanakan Tridharma perguruan tinggi dalam mengembangkan serta menyebarluaskan ilmu pengetahuan dan teknologi [1]. Dalam melaksanakan kegiatannya Tridharma nya, seorang dosen melakukan pendidikan dan pengajaran, penelitian serta pengabdian kepada masyarakat sesuai dengan bidang keilmuannya masing-masing.

Dosen juga merupakan komponen utama dalam sebuah pendidikan di perguruan tinggi [2], sehingga diperlukan sebuah kompetensi tertentu untuk menjadi seorang pendidik. Kompentensi pendidik merupakan satu kesatuan pengetahuan dan keterampilan serta nilai-nilai atau norma dalam berperilaku yang dimiliki yang digunakan untuk melaksanakan tugas utama dosen dalam melaksanakan tugas-tugas profesionalnya. Sifat profesional seorang dosen merupakan pengetahuan atau keahlian serta kecakapan dalam melaksanakan kegiatan dalam suatu pengembangan ilmu pengatahuan yang memenuhi standar mutu dalam pelaksanaan kegiatan pendidikan.

Bagi suatu perguruan tinggi, pelaksanaan tugas-tugas utama seorang dosen ini sudah tentu memerlukan suatu pengawasan serta evaluasi sebagai suatu bentuk umpan balik kegiatan yang telah dilaksanakan sehingga dapat memberikan suatu penilaian serta dimungkinkan suatu perbaikan secara periodik sebagai bentuk pertangguangjawaban mengenai profesi dosen dan untuk pelaporan kenerja kepada pimpinan perguruan tinggi. Kinerja dapat menjadi ukuran seberapa besar ketercapaian atas pelaksanaan pekerjaan yang diberikan kepada seseorang yang dipengaruhi beberapa faktor antara laian motivasi, kemampuan serta konsep diri [3].

Beberapa manfaat evaluasi dalam pelaksanaan penilaian beban kerja dosen (BKD) ini antara lain akan meningkatkan profesianalisme serta produktivitas dosen pada saat melaksanakan tugasnya, sebagai evaluasi terhadap proses dan luaran kegiatan pendidikan pada suatu perguruan tinggi, membangun suatu suasana akademik atau ilmiah dalam pelaksanaan kegiatan pendidikan di perguruan tinggi serta untuk meningkatkan kualitas pendidikan nasional utamanya pendidikan tinggi [4]. Kualitas dan daya mutu dosen akan mempengaruhi kualitas serta mutu akademik suatu perguruan tinggi. Peningkatan kualitas dan mutu dosen dapat diketahui dengan pelaksanaan penilaian kenerja dosen yang dilakukan secara berkala [5].

Penilaian beban kerja dosen secara berkala yang biasanya dilaksanakan di akhir semester pada beberapa perguruan tinggi saat ini masih cenderung dilaksanakan dengan pendataan dengan melampirkan bukti-bukti dokumen secara fisik dengan perhitungan penilaian berdasarkan rubrik BKD pada masingmasing bidang yang masih dilakukan secara manual dan belum dilakukan penyimpanan dokumen bukti fisik secara digital. Hal tersebut tentunya kurang efisien dalam pelaporan serta menyulitkan apabila suatu saat kembali membutuhkan dokumen-dokumen tersebut. Beban pekerjaan yang tinggi dalam melaksanakan kegiatan tridharma perguruan tinggi juga semakin menyulitkan bagi seorang dosen dalam melakukan pelaporan kegiatan tridharma yang telah dilaksanakannya.

Berdasarkan latar belakang tersebut maka penilaian beban kerja dosen dapat dikembangkan menjadi menjadi sistem informasi dalam melakukan pengelolaan kegiatan tridharma perguruan tinggi. Sistem informasi merupakan suatu sistem yang dikembangkan manusia yang terdiri dari komponen-komponen dalam suatu himpunan atau organisasi yang digunakan untuk mencapai suatu tujuan yakni memberikan informasi bagi pengambil keputusan [6].

Diharapkan, sistem informasi beban kerja dosen dapat membantu dalam pengarsipan serta pengelolaan dokumen - dokumen beban kerja dosen sehingga pengelolaan kegiatan tridharma menjadi lebih efisien dan efektif [7] dan membantu tugas seorang dosen dalam pelaksanaan sebagai pendidik profesionalnya dengan tetap melaksanakan evaluasi kegiatan - kegiatan yang telah dilaksanakannya melalui sistem penilaian beban kerja dosen (BKD). Antar muka sistem ini dikembangkan dalam basis web untuk akses dalam pendataan kegiatan yang dilaksanakan serta dilengkapi perhitungan secara otomatis dari rubrik BKD sehingga akan memberikan dampak efisiensi serta efektivitas dalam melakukan evaluasi dan pelaporan kegiatan tridharma yang dilaksanakan oleh sorang dosen.

\section{METODOLOGI PENELITIAN}

\subsection{Objek Penelitian}

Objek dalam penelitian ini adalah kegiatan pengelolaan serta evaluasi dan penilaian beban kerja dosen yang dilaksanakan setiap semester dengan merujuk pada isian rubrik beban kerja dosen yang ditetapkan oleh Ristekdikti 


\subsection{Metode Pengembangan Sistem}

Dalam penelitian ini menggunakan metode pengembangan sistem System Development Life Cycle (SDLC) Waterfall model. Metode pengembangan sistem ini menggunakan konsep linier sequensial, sistematis berurutan pada setiap tahapannya [8]. Tahapan pada metode Waterfall antara lain:

a) Communication

Kegiatan ini diperlukan untuk mengetahui permasalahan dan kebutuhan dan keinginan yang akan dicapai pada pengembangan sebuah sistem, termasuk pengumpulan data yang dibutuhkan.

b) Planning

Pada tahapan ini direncanakan kegiatan yang akan dilaksanakan, penjadwalan kegiatan dalam pengembangan sistem termasuk pula resiko-resiko yang mungkin ada serta identifikasi sumber daya yang dibutuhkan.

c) Modelling

Tahapan ini melakukan perancangan arsitekstur sistem untuk mengetahui gambaran dari sebuah sistem yang akan dikerjakan. Perancangan ini meliputi arsitektur software, algoritma, struktur datanya sampai dengan desain antar mukanya.

d) Contruction

Pada tahap ini dilakukan penerapan perancangan ke dalam bahasa pemrograman (coding) dan dilaksanakan pengujian untuk mengetahui atau menemukan kesalahan dalam proses pengembangan sistem ini.

e) Deployment

Pada tahap ini dilaksanakan implementasi perangkat lunak kepada pengguna, dimungkinkan masih ada perbaikan berdasarkan umpan balik atau evaluasi untuk memastikan sebuah sistem berjalan sesuai dengan perencanaan dan kebutuhan.

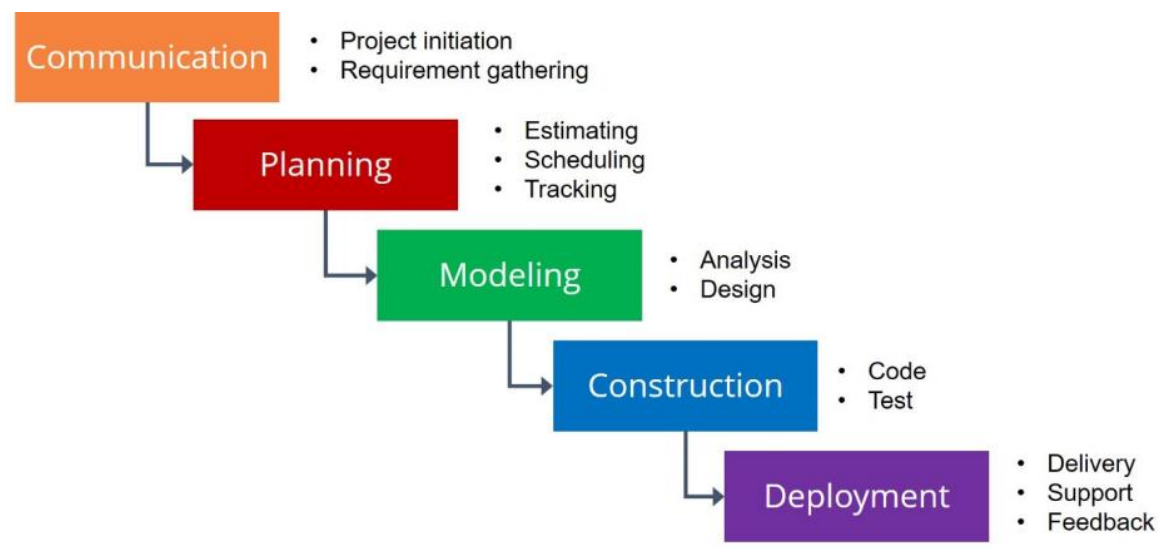

Gambar 1. Tahapan Metode Waterfall [8]

\subsection{Metode Perancangan}

Metode dalam perancangan sistem ini menggunakan model Object Oriented Analysis (OOA) yang merupakan pendekatan untuk menentukan fungsional sebuah perangkat lunak yang memungkinkan adanya kolabaroasi antar objek [9]. Salah satu penerapan pendekatan berbasis OOA adalah penggunaan Unified Modelling Language (UML) untuk permodelan sebuah sistem. UML merupakan alat bantu untuk pengembangan sebuah sistem informasi karena UML juga memberikan sebuah alat permodelan berbasi visual yang dapat membantu pengembang sistem dalam mengkomunikasikan perancangan sistem yang akan dikembangkan dengan penggunanya. Perancangan sistem tersebut dapat digambarkan dengan diagram usecase yang dapat digunakan untuk menganalisa kebutuhan serta dalam memahami alur proses sebuah sistem [6].

\section{HASIL DAN PEMBAHASAN}

\subsection{Use case Sistem}

Untuk menjelaskan gambaran usulan kebutuhan sistem dari sudut pandang pengguna dapat menggunakan usecase diagram. Use case merupakan bagian yang menjelaskan fungsionalitas dari sebuah 
sistem atau menggambarkan bagaimana seseorang yang diwakili oleh aktor dalam menggunakan sebuah sistem [10]. Alur sistem usecase ini menjelaskan proses dalam sistem penilaian beban kerja dosen yang meliputi pengisian master data-data BKD serta proses penilaian oleh asesor dan pelaporan hasil evaluasi penilaian BKD. Gambar 2 menjelaskan sistem usecase pada sistem penilaian beban kerja dosen.

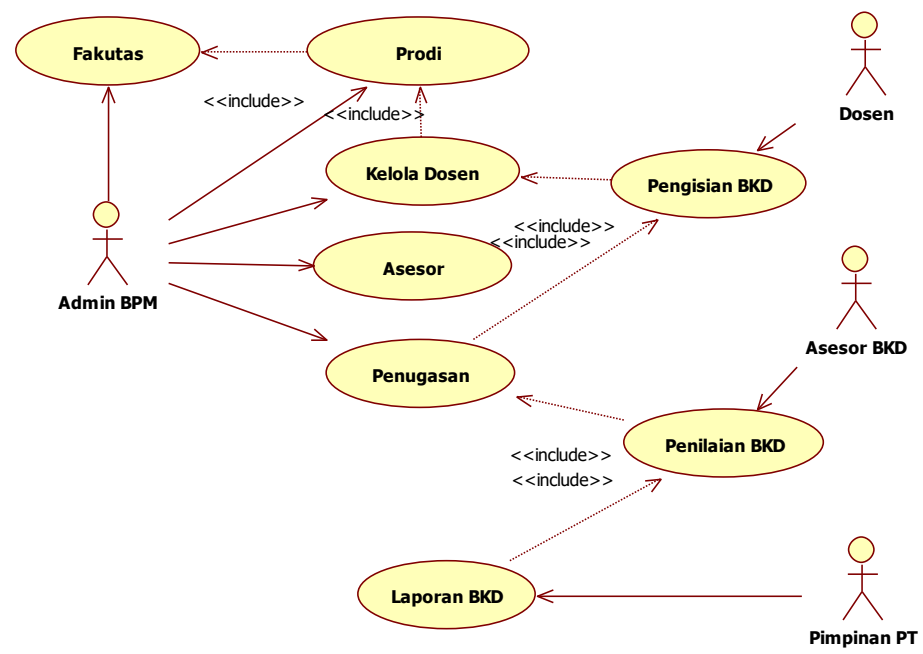

\subsection{Desain Tabel}

Gambar 2. Use Case Sistem

Dalam perancangan sistem penilaian beban kerja dosen ini, disusun sebanyak 67 tabel yang digunakan untuk kebutuhan master data serta untuk pengelolaan data isian dari kegiatan tridharma yang meliputi kegiatan pendidikan dan pengajaran, penelitian serta kegiatan pengabdian masyarakat dan penunjang. Gambar 3 merupakan perancangan tabel-tabel dari sistem penilaian beban kerja dosen.

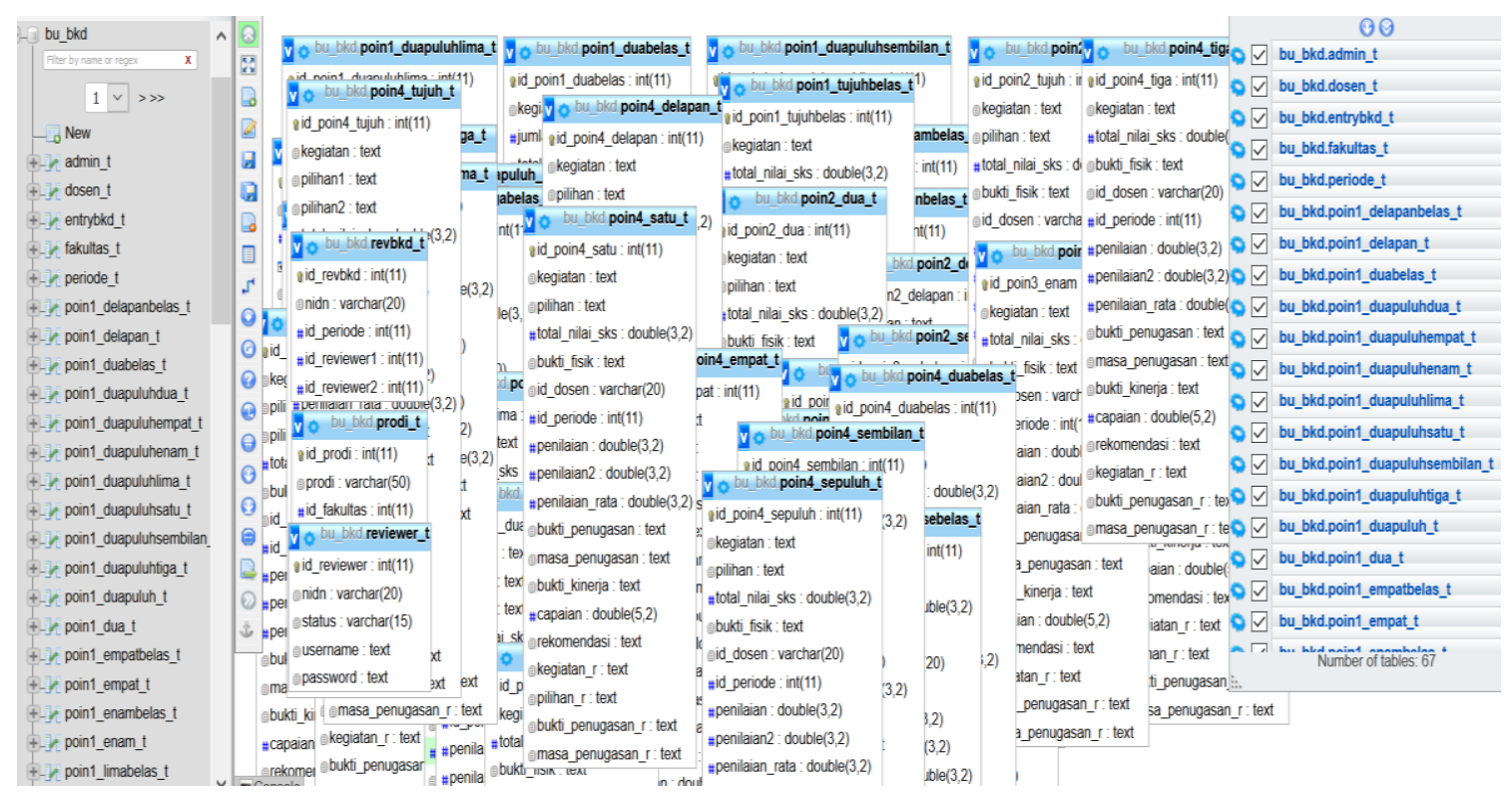

\section{Gambar 3. Desain Tabel}

Desain interface antar muka dari sistem penilaian BKD ini dimulai dari halaman login untuk memverifikasi hak akses yang digunakan oleh masing-masing user. Setelah verifikasi halaman login berhasil maka sistem akan menampilkan halaman dashboard admin menampikan keseluruhan menu pada sistem penilaian BKD yang meliputi Master data, rekap BKD, rekap bidang pendidikan, rekap bidang penelitian, rekap bidang pengabdian serta rekap bidang penunjang. Pada tampilan ini juga diberikan informasi berupa grafik yang menampilkan data pengguna yang telah melakukan pengisisan BKD. Halaman dashboard admin sistem penilaian BKD ditunjukan pada gambar 4 berikut ini. 


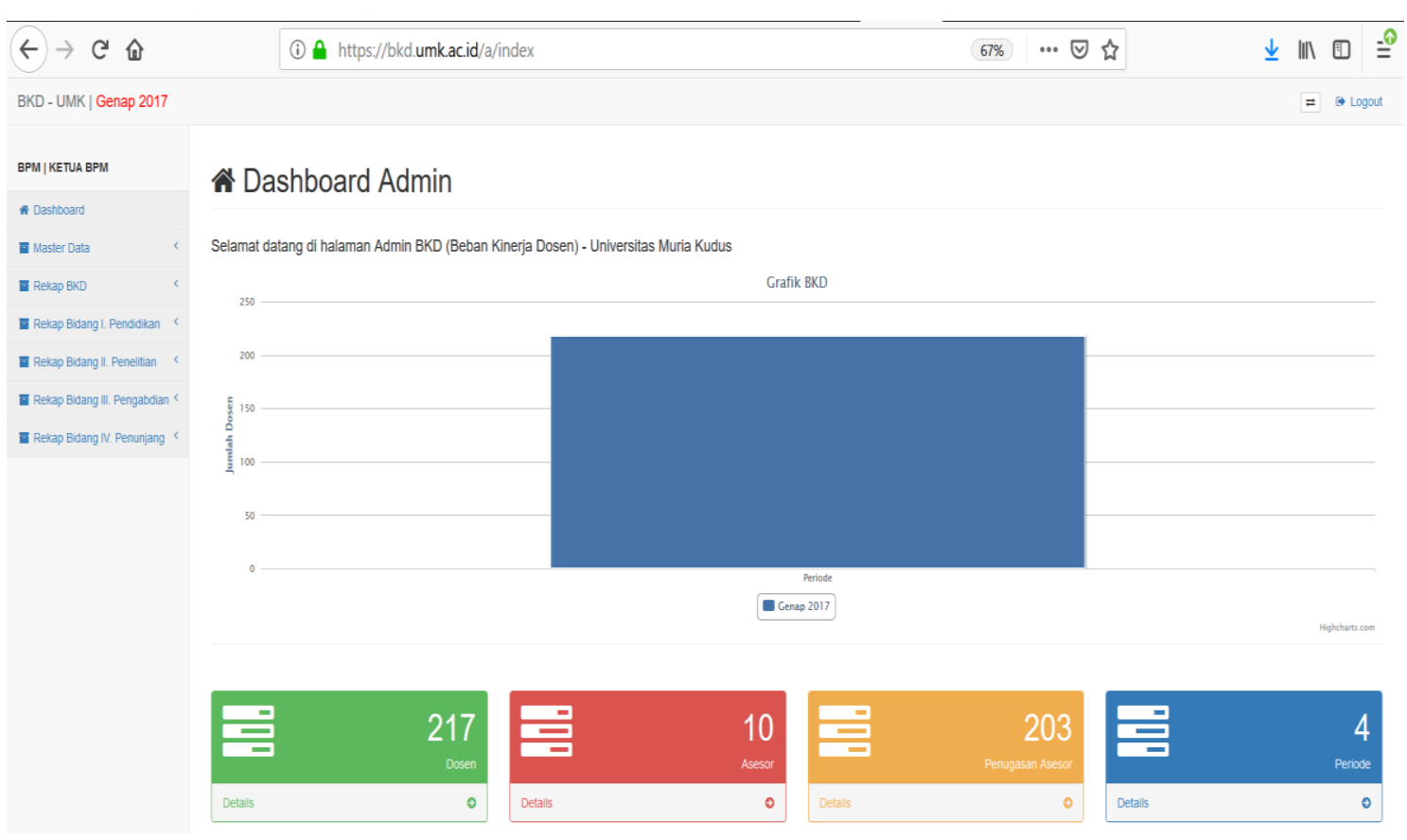

Gambar 4. Tampilan Halaman Dashboard

Pada gambar 5 terdapat tampilan menu yang merupakan isian dari master data sistem penilaian BKD. Data -data tersebut harus dilengkapi terlebih dahulu untuk dapat melanjutkan ke proses pengisian serta evaluasi penilaian BKD oleh asesor yang telah ditugaskan.

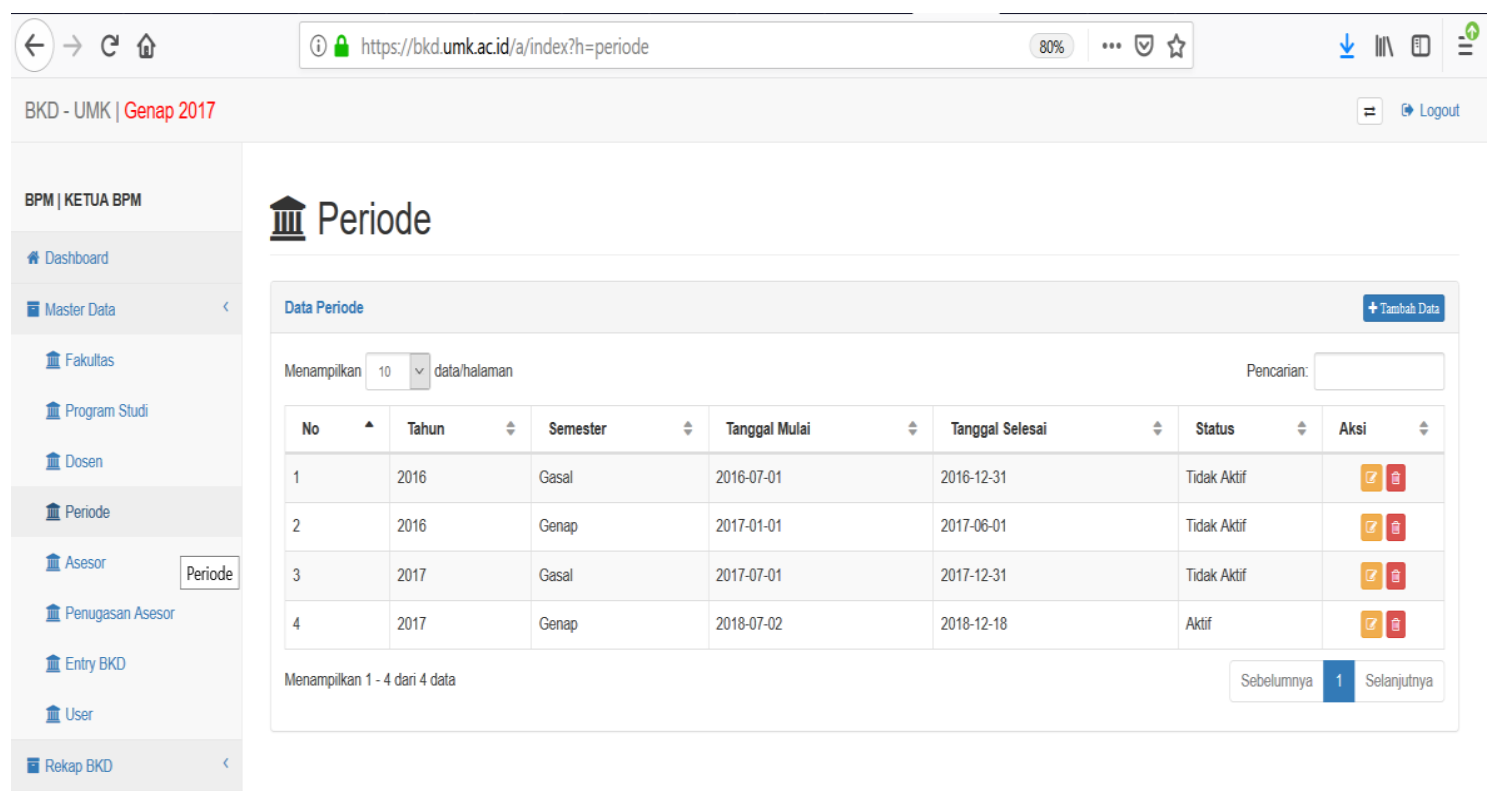

\section{Gambar 5. Form Master Data}

Dalam proses penilaian beban kerja dosen dilakukan evaluasi oleh asesor yang bertugas untuk melakukan validasi terhadap kegiatan tridharma yang telah dilakukan oleh dosen. Proses penugasan asesor tersebut dapat dilihat pada gambar 6 berikut ini. 


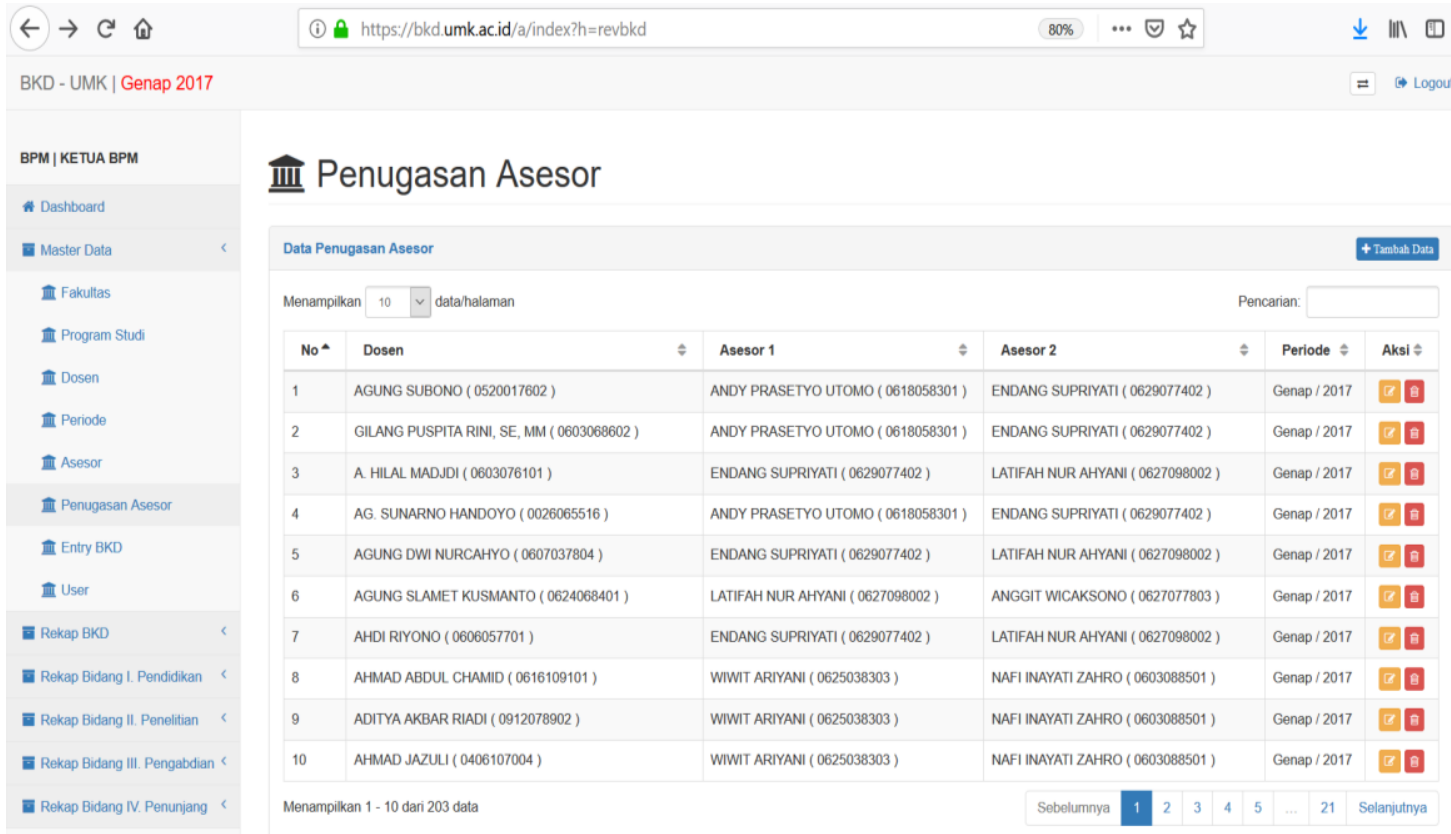

Gambar 6. Form Penugasan Asesor BKD

Pengisian kegiatan tridharma yang meliputi kegiatan bidang pendidikan, penelitian, pengabdian serta bidang penunjang dilakukan melalui halaman entry BKD. Gambar 7 berikut ini merupakan salah satu form pengisian untuk kegiatan Tridarma bidang pendidikan.

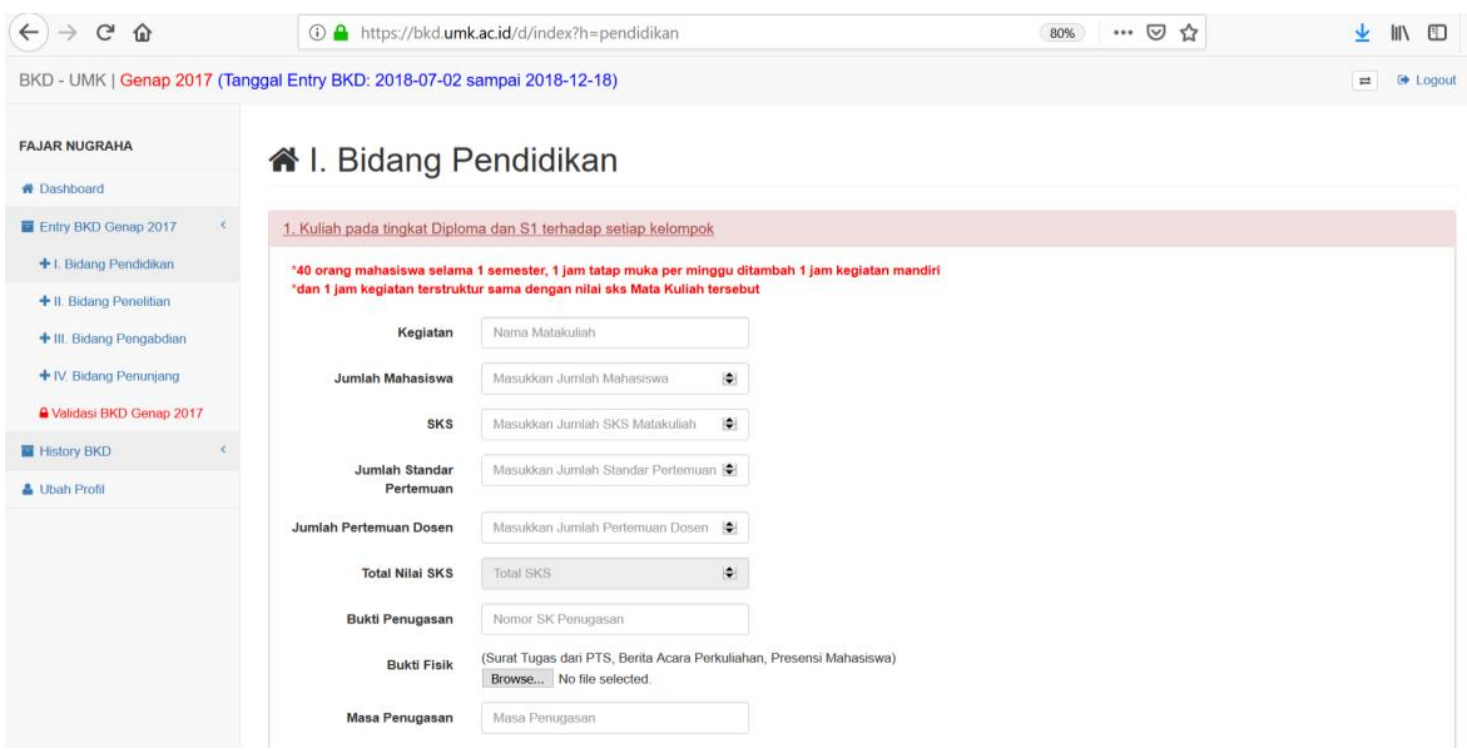

Gambar 7. Form Pendataan Kegiatan Bidang Pendidikan

Gambar 8 menunjukan rekapitulasi hasil evaluasi dan penilaian BKD yang telah dilakukan oleh asesor BKD beserta format laporan dari rekapitulasi kegiatan penilaian beban kerja Dosen yang menampilkan informasi kegiatan tridharma, beban kerja beserta bukti penugasan, masa penugasan, capaian kinerja beserta capaiannya serta hasil penilaian atau rekomendasi asesor. Dalam rekapitulasi serta laporan ini juga dapat digunakan untuk mengetahui capaian kinerja dosen yang kinerjanya telah memenuhi maupun yang tidak sesuau dengan peraturan. 

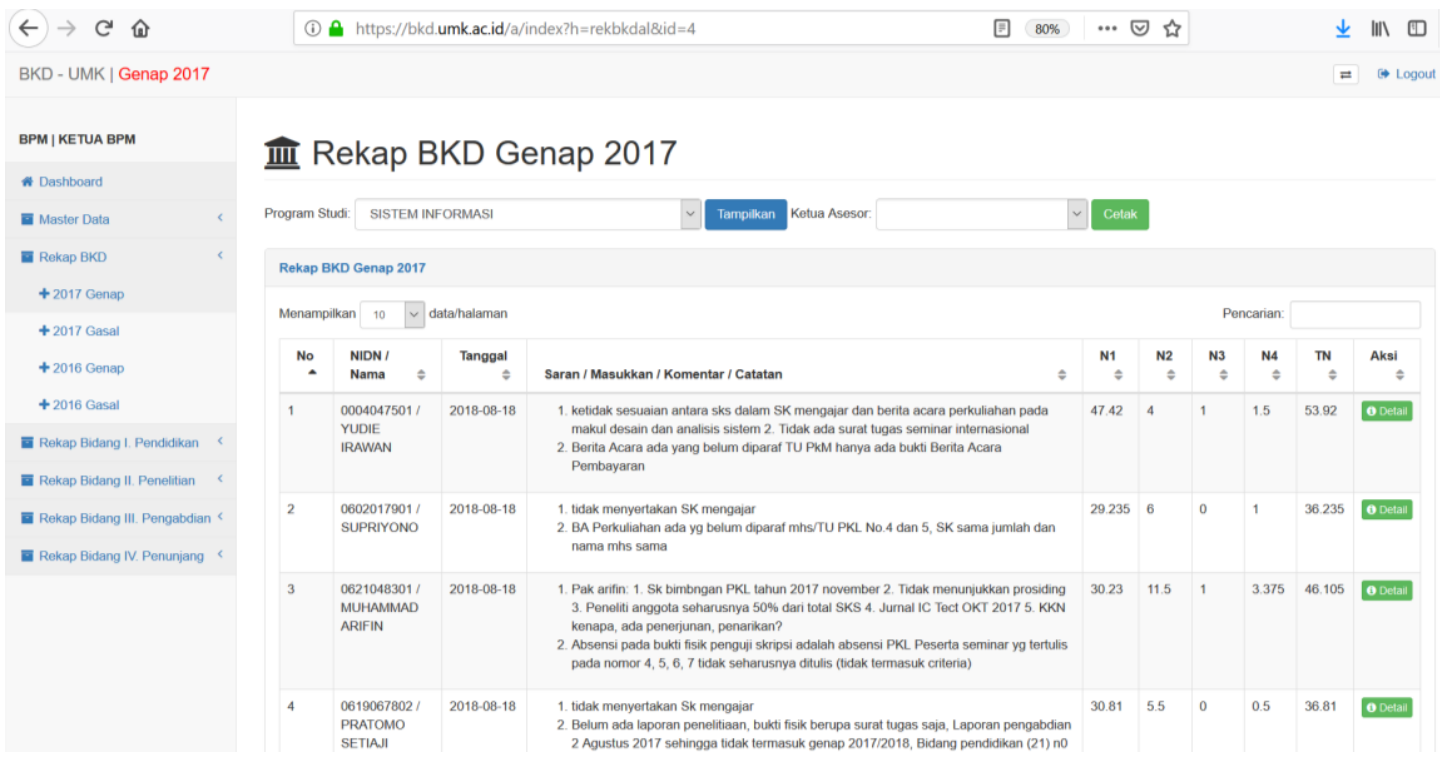

Gambar 8. Rekapitulasi Pengisian BKD

Gambar 9 merupakan format laporan dari rekapitulasi kegiatan penilaian beban kerja Dosen yang menampilkan informasi kegiatan tridharma, beban kerja beserta bukti penugasan, masa penugasan, capaian kinerja beserta capaiannya serta hasil penilaian atau rekomendasi asesor.

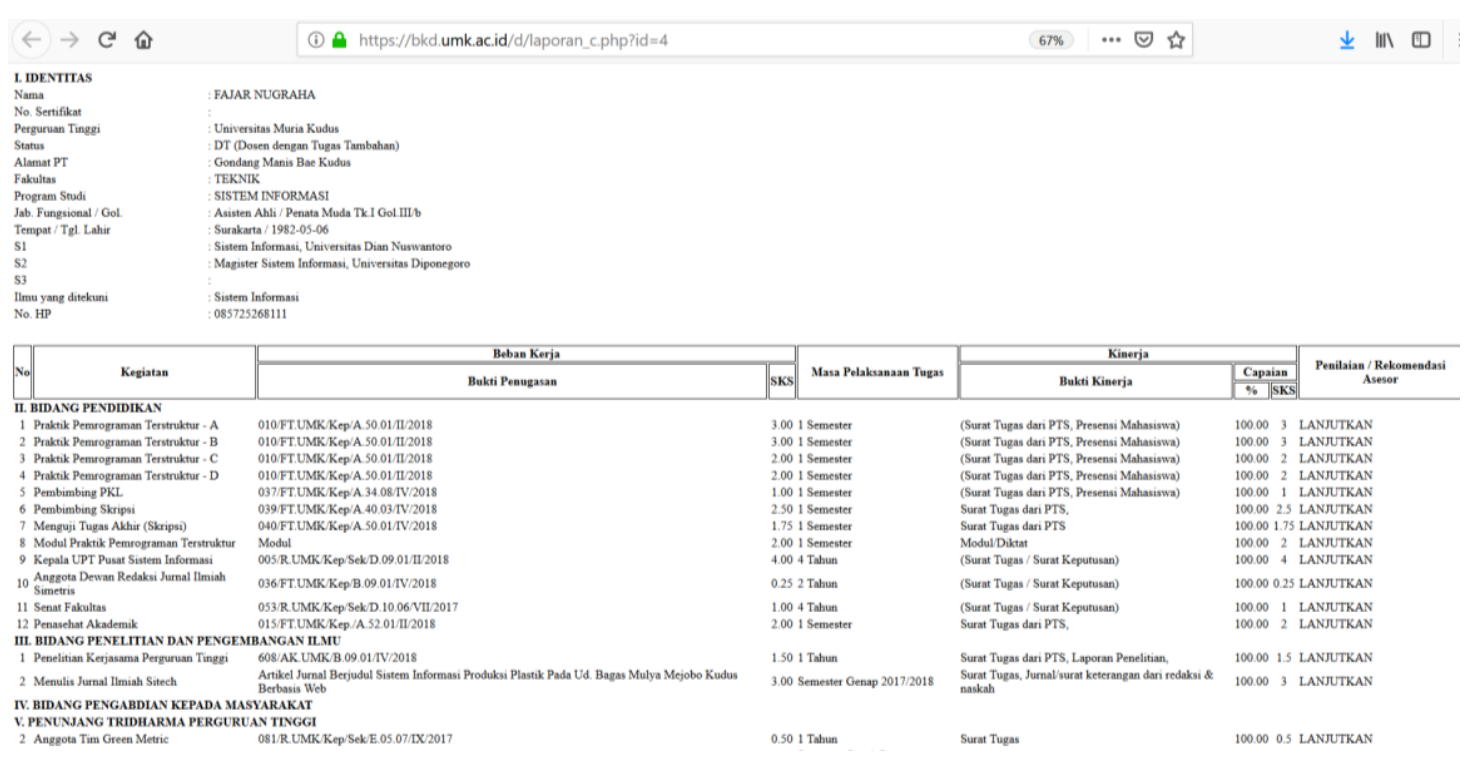

Gambar 9. Laporan Penilaian BKD

\section{KESIMPULAN} lain:

Perancangan serta pengembangan sistem penilaian beban kerja Dosen ini dapat disimpulkan antara

a) Hasil dari penelitian ini adalah merancang bangun sebuah sistem penilaian beben kerja dosen yang dapat digunakan untuk pengelolaan data tridharma dosen, evaluasi serta penilaian dan pelaporan kinerja dosen.

b) Metode pengembangan sistem yang digunakan adalah waterfall sementara metode perancangan sistem menggunakan unified modeling language.

c) Sistem penilaian beban kerja Dosen ini menggunakan data-data master antara lain data fakultas, program studi, dosen, periode, asesor, serta data penugasan. 
d) Proses yang dikelola dalam sistem ini antara lain proses pengisian data (kegiatan pendidikan dan pengajaran, penelitian, pengabdian serta kegiatan penunjang), penilaian isian BKD oleh tim asesor serta rekapitulasi pengisian BKD.

e) Sistem penilaian beban kerja Dosen ini dikembangkan dengan bahasa pemrograman $P H P$ serta menggunakan database $M y S Q L$.

\section{DAFTAR PUSTAKA}

[1] "Undang - Undang No 14 Tahun 2005 Tentang Guru dan Dosen.” Jakarta, 2005.

[2] M. A. Irwansyah, "Sistem Informasi Repository Digital Beban Kerja Dosen," J. Edukasi dan Penelit. Inform., vol. 1, no. 1, pp. 18-23, 2015.

[3] Sunarni and B. Setyadin, "Analisis Pelaksanaan Beban Kerja Dosen (BKD)," Manaj. Pendidik., vol. 25, no. 1, pp. 47-56, 2016.

[4] D. Dikti, "Pedoman Beban Kerja Dosen dan Evaluasi Pelaksanaan Tridharma Perguruan Tinggi." Dirjen Dikti, Jakarta, 2010.

[5] M. E. Setyobudi, A. Rosidi, and Sudarmawan, "Sistem Informasi Penilaian Kinerja Dosen Di Amikom Cipta Darma Surakarta," J. Data Manaj. dan Teknol. Inf., vol. 16, no. 4, pp. 47-54, 2015.

[6] A.-B. Bin Ladjamudin, Analisis dan Desain Sistem Informasi. Yogyakarta: Graha Ilmu, 2005.

[7] T. Arifianto, "Implementasi Sistem Informasi Beban Kerja Dosen (BKD) Di Stmik Yadika Bangil," in Seminar Nasional Sistem Informasi, 2017, no. September, pp. 776-787.

[8] Roger S. Pressman, Software Engineering: a practitioner's approach, 7th ed. New York: McGrawHill, 2010.

[9] J. L. Whitten, L. D. Bentley, and K. C. Dittman, Metode Desain dan Analisis Sistem. New York: McGraw Hill, 2004.

[10] Sholiq, Permodelan Sistem Informasi Berorientasi Obyek dengan UML. Yogyakarta: Graha Ilmu, 2006. 